\title{
The role of cortisol and interleukin-10 gene expression patterns in exhaustive exercise
}

\author{
F. A. EHIAGHE ${ }^{1,2,3^{*}}$, C. C. ONYENEKWE ${ }^{3}$, I. J. EHIAGHE ${ }^{3,2}$, C. O. AKOSILE ${ }^{4}$ and \\ D. E. AGBONLAHOR ${ }^{2}$
}

${ }^{I}$ Department of Hematology, College of Health Sciences, Igbinedion University, Okada, Nigeria. ${ }^{2}$ Lahor Research and Medical Centre, 121 Old Benin-Agbor Road, Benin City, Nigeria.

${ }^{3}$ Department of Medical Laboratory Sciences, Nnamdi Azikiwe University, Awka, Nigeria.

${ }^{4}$ Department of Medical Rehabilitation, Nnamdi Azikiwe University, Awka, Nigeria. ${ }^{*}$ Corresponding author; E-mail: fredleo2547@yahoo.com

\section{ACKNOWLEDGEMENTS}

This study was supported by Lahor Research Laboratory and Bioscience Research Group.

\begin{abstract}
Cortisol is a steroid hormone produced by the zona fasciculate of the adrenal cortex in response to stress, whereas interleukin-10 is an important immunoregulatory cytokine which increases with exercise. Cortisol most often is viewed as having a counter-productive role in exercise. Therefore, the objective of this study was to establish the critical role of cortisol during exercise. Moreover, the immunoregulatory role of interleukin-10 in limiting host immune response to stress was also investigated. The longitudinal study randomly selected twenty-five young apparently healthy students from the Faculty of Health Sciences and Technology, Nnamdi Azikiwe University, Nnewi Campus, aged $24.3 \pm 3$ years. The participating male undergraduate students were placed under resting and relaxed conditions for 48 hours prior to the test. Their blood pressures and pulse rates were taken and fasting blood sugar determined as a prerequisite screening before enlisting in the study. The subjects took part in an endurance race using the Bruce treadmill protocol for sub-maximal exercise for a maximum of 21 minutes. The target heart rate on the treadmill was $60-80$ percent of the heart rate reserve. Blood samples were collected from the participants before commencement of the study, at 1 hour, 4 hours and 24 hours post exercise. Serum cortisol $(\mathrm{nmol} / \mathrm{L})$, troponin I $(\mathrm{ng} / \mathrm{ml})$, creatine kinase $\mathrm{MM}(\mathrm{ng} / \mathrm{ml})$ was determined using enzyme-linked immunosorbent assay methods. Interleukin-10 genes expression patterns were detected using reverse transcriptase polymerase chain reaction method. There was a significant increase in cortisol, troponin and creatine kinase $\mathrm{MM}$ level at 1 hour post exhaustive exercise when compared with pre-exercise stage $(\mathrm{F}=$ $6.032, \mathrm{P}=0.000),(\mathrm{F}=4.551, \mathrm{P}=0.000)$ and $(\mathrm{F}=10.282, \mathrm{P}=0.000)$ respectively. The expression patterns of interleukin-10 genes were up-regulated at 4 hours post exercise and sustained till 24 hours post exercise $\left(\chi^{2}=\right.$ $50, \mathrm{P}=0.000)$. Post exercise stress activates the release of cortisol, and interleukin-10 genes to reinstate homeostasis through modulation of the immune response.

(C) 2017 International Formulae Group. All rights reserved.
\end{abstract}

Keywords: Homeostasis, immune response, interleukin-10 genes, cortisol, stress. 


\section{INTRODUCTION}

Cortisol is a steroid hormone produced by the zona fasciculate of the adrenal cortex in the adrenal gland, this hormone plays a vital role in the body's defense mechanism when dealing with stress as well as being important in blood glucose regulation (Hackney and Walz, 2013). Interleukin 10 is known to play a significant role in immune regulation involving both $\mathrm{T}$ helper 2 (Th2) and T helper 1 (Th1), thereby enhancing normal tissue homeostasis (Stenberg et al., 2000). Physical exercise is important for maintaining physical fitness and strengthening the immune system (Stampfer et al., 2000; Hu et al., 2001; Gosker and Schol, 2008).

Cortisol most often is viewed as having a counter-productive role in physical exercise. Therefore, the objective of this article was to establish the critical role of cortisol during exercise. Moreover, the immunoregulatory role of interleukin-10 in limiting host immune response to stress was also investigated. The emphasis is specifically to correct several false impressions about the counter-productive roles of cortisol by some exercise specialists. The view by some exercise specialist is that the elevated cortisol level during exercise can lead to a predominance of catabolism in the body (Hackney and Walz, 2013). This is an oversimplification of the hormonal action of cortisol.

\section{MATERIALS AND METHODS}

Study area

The study was carried out in the Faculty of Health Sciences and Technology, Nnamdi Azikiwe University, Nnewi Campus, Nigeria.

\section{Subjects}

Twenty five (25) healthy young male undergraduate students with an average age of $24.3 \pm 3$ years and body mass index of $22.7 \pm 1.8\left(\mathrm{~kg} / \mathrm{m}^{2}\right)$ participated fully in the study (Table 1). Patient consent was obtained from the subjects.

\section{Inclusion criteria}

This study was limited to apparently healthy young male undergraduate students of the Faculty of Health Sciences, Nnamdi Azikiwe University, Nnewi Campus, Nigeria, within 18 and 35 years of age who are willing to participate in the study.

\section{Exclusion criteria}

Young male with an underlying history of illness, e.g. Hypertension, irregular heart rate, glucose utilization disorders, asthmatics, sickle cell anemia and other forms of anemia were excluded. Those currently undertaking examination were excluded. Those that engage in strenuous activities such as (professional athletes, welders etc) were excluded. Subjects currently on antioxidant supplementation, alcohol and any antimicrobial agents were excluded.

\section{Research design}

The research design was the longitudinal experimental design.

\section{Study design}

The subjects were encouraged to eat balance diet two hours prior to the endurance race and avoid any strenuous activity during the course of the research. Upon arrival at the venue of the research, their height $(\mathrm{H})$ and weight (W) was measured and recorded and they were allowed to rest for at least ten minutes. The subjects took part in an endurance race using the Bruce treadmill 
protocol for sub maximal exercise. The exercise protocol started at $2.7 \mathrm{~km} / \mathrm{hr}$ and a $10 \%$ grade and increased by $2 \%$ every 3 minutes in a step-like manner to a final stage at $9.6 \mathrm{~km} / \mathrm{hr}$ with a $22 \%$ grade as described by Vanessa and Elizabeth (2000). The target heart rate on the treadmill was $60-80$ percent of the heart rate reserve (HRR).The difference between maximal heart rate (MHR) and resting heart rate (RHR).The HRR was calculated using the formula:

HRR $=$ MHR-RHR.

$M H R=220$-age in years. As described by Ogwumike et al. (2011). The subjects continued this for twenty-one minutes or stopped when they are tired. Fourteen out twenty-five subjects were exhausted before the twenty-one minutes. Blood sample was collected at four different time points: before, one hour, four hours and twenty-four hours post exercise stages.

\section{Collection of blood samples}

Six milliliters of venous blood sample were collected from the medial cubital vein using vacutainer and needle from each of the subjects shared equally into plain containers and RNAgard vacutainer for total lymphocyte RNA isolation.

\section{Determination of serum cortisol level}

Enzyme-linked immunosorbent assay was used in the determination of the level of serum cortisol in the serum as previously been described by Ehiaghe et al. (2014). In brief, $20 \mu \mathrm{l}$ of standard or sample(s) was added per microplates. $200 \mu \mathrm{l}$ cortisol hormone conjugate was added to the standard or sample(s) and covered with a sealing tape. It was incubated at room temperature for 1 hour. The solution was discarded and microplates washed three times with $300 \mu 1$ of $1 \mathrm{X}$ wash solution. $100 \mu \mathrm{l}$ of tetramethyl benzidine one step substrate was added to each micro plate and incubated for 15 minutes at room temperature in the dark with gentle shaking. $100 \mu \mathrm{l}$ of stop solution was added to each micro plate. The intensity of the color developed was measured at $450 \mathrm{~nm}$ wavelength using stat $f_{a x}{ }^{\circledR} 4700$ micro strip reader.

\section{Determination of serum troponin inhibitory level}

Enzyme-linked immunosorbent assay (ELISA) was used in the determination of serum troponin inhibitory level as previously been described by Goett et al. (2011). In brief, $100 \mu 1$ volume of standards, specimens, and controls were dispensed into appropriate wells. It will be gently mixed for 10 seconds. A $100 \mu 1$ volume of enzyme conjugate reagent was added into each well. It was thoroughly mixed for 30 seconds and incubated at room temperature for 90 minutes. The incubation mixture was removed by flicking plate contents into a waste container. The wells were rinsed five times with wash solution. The wells sharply strike onto absorbent paper to remove all residual water droplets. A $100 \mu$ l volume of TMB reagent dispense into each well and incubated at room temperature for 20 minutes. The reaction was stopped by adding $100 \mu \mathrm{l}$ volume of stop solution to each well. It was gently mixed for 30 seconds. The absorbance was read at $450 \mathrm{~nm}$ with a microtitre well reader within 15 minutes.

\section{Determination of serum creatine kinase- MM level}

Enzyme-linked immunosorbent assay (ELISA) was used in the determination of serum creatine level as previously been described by Marianne et al. (2012). In brief, $20 \mu 1$ volume of standard or sample(s) was added per microplates. A $200 \mu \mathrm{l}$ volume hormone conjugate was added to the standard 
or sample(s) and covered with a sealing tape. It was incubated at room temperature for one hour. The solution was discarded and microplates washed three times with $300 \mu \mathrm{l}$ volume of $1 \mathrm{X}$ wash solution. A $100 \mu \mathrm{l}$ volume of tetraethyl benzidine one step substrate was added to each micro plate and incubated for 15 minutes at room temperature in the dark with gentle shaking. A $100 \mu$ volume of stop solution was added to each micro plate. The intensity of the color developed was read at $450 \mathrm{~nm}$ wavelength using stat fax ${ }^{\circledR} 4700$ micro strip reader.

Polymerase chain reaction methods Total RNA Extraction using the ZYMO RESEARCH Whole-Blood RNA MiniPrep

Total RNA was extracted using the ZR Whole -Blood RNA MiniPrep with catalog number R1020 and R1021 by ZYMO RESEARCH CORPORATION according to manufacturer's specification at the Lahor.

Research Laboratory and Medical centre, 121 Old Benin- Agbor Road, Benin City, Edo State, Nigeria. $70 \mu \mathrm{l}$ of the Total RNA extracted was transferred into an RNA. Stable tube supplied by Biomatrica with catalog number 93221-001 for storage of Total RNA at room temperature after proper drying.

One Taq One-Step reverse transcriptase polymerase chain reaction

The extracted Total RNA was retrotranscribed and amplified using One Taq One Step RT-PCR kit with catalog number NEB E5315S by NEW ENGLAND BioLabs incorporation according to the manufacturer's specification. Interleukin 10 genes forward and reverse primers (ATGCACAGCTCAGCACTGC;

TCAGTTTCGTATCTTCATTGTC) were used to target lymphocyte template using Peltier thermal cycler polymerase chain reaction machine at the Lahor Research Laboratory and Medical Centre, 121, Old Benin-Agbor Road, Benin City, Edo state, Nigeria. The system components were thaw and mixed by inverting ten times. The PCR was performed in a $50 \mu \mathrm{l}$ reaction mixture containing $25 \mu \mathrm{l}$ One Taq one-step reaction master mix $(2 x), 2 \mu l$ One Taq one-step enzyme mix (2x), $2 \mu$ l of each gene-specific forward primer $(10 \mu \mathrm{M}), 2 \mu \mathrm{l}$ of each genespecific reverse primer $(10 \mu \mathrm{M}), 9 \mu \mathrm{l}$ of nuclease-free water and $10 \mu \mathrm{l}$ of the RNA template(s) was added last. The PCR was started immediately as follows: Reverse transcriptase at $48{ }^{0} \mathrm{C}$ for 30 minutes, initial denaturation at $94{ }^{\circ} \mathrm{C}$ for 1 minute, denaturation at $94{ }^{\circ} \mathrm{C}$ for 15 seconds, annealing at $54{ }^{\circ} \mathrm{C}$ for 30 seconds, extension at $68{ }^{\circ} \mathrm{C}$ for 1 minute, Go to the denaturation step for 39 cycles, final extension at $68{ }^{\circ} \mathrm{C}$ for 5 minutes and final holding at $4{ }^{\circ} \mathrm{C}$ forever. Five micro liters of the amplified PCR products were analyzed on $1 \%$ agarose gel containing ethidium bromide in $1 \mathrm{X}$ Tris EDTA buffer. Electrophoresis was performed at 90 volt for 30 minutes with the EDVOTEK tetra source electrophoresis machine, Bethesda, USA. The targeted genes were visualized by Wealtec Dolphin-Doc UV transilluminator and photographed. Molecular weights were calculated using molecular weight standard of the marker. The graphical analysis was done on a bar chart.

The extracted Total RNA was retrotranscribed and amplified using One Taq One Step RT-PCR kit with catalog number NEB E5315S by NEW ENGLAND BioLabs incorporation according to the manufacturer's specification. Interleukin 10 genes forward and reverse primers (ATGCACAGCTCAGCACTGC; TCAGTTTCGTATCTTCATTGTC) were used to target lymphocyte template using Peltier thermal cycler polymerase chain 
reaction machine at the Lahor Research Laboratory and Medical Centre, 121, Old Benin-Agbor Road, Benin City, Edo state, Nigeria. The system components were thaw and mixed by inverting ten times. The PCR was performed in a $50 \mu \mathrm{l}$ reaction mixture containing $25 \mu \mathrm{l}$ One Taq one-step reaction master mix (2x), $2 \mu 1$ One Taq one- step enzyme mix $(2 x), 2 \mu l$ of each gene-specific forward primer $(10 \mu \mathrm{M}), 2 \mu \mathrm{l}$ of each geneat $68{ }^{\circ} \mathrm{C}$ for 1 minute, Go to the denaturation step for 39 cycles, final extension at $68{ }^{\circ} \mathrm{C}$ for 5 minutes and final holding at $4{ }^{\circ} \mathrm{C}$ forever. Five micro liters of the amplified PCR products were analyzed on $1 \%$ agarose gel containing ethidium bromide in $1 \mathrm{X}$ Tris EDTA buffer. Electrophoresis was performed at 90 volt for 30 minutes with the EDVOTEK tetra source electrophoresis machine, Bethesda, USA. The targeted genes were visualized by Wealtec Dolphin-Doc UV transilluminator and photographed. Molecular weights were calculated using molecular weight standard of the marker. The graphical analysis was done on a bar chart.

Specific reverse primer $(10 \mu \mathrm{M}), 9 \mu \mathrm{l}$ of nuclease-free water and $10 \mu \mathrm{l}$ of the RNA template(s) was added last. The PCR was started immediately as follows: Reverse transcriptase at $48{ }^{0} \mathrm{C}$ for 30 minutes, initial denaturation at $94{ }^{0} \mathrm{C}$ for 1 minute, denaturation at $94{ }^{0} \mathrm{C}$ for 15 seconds, annealing at $54{ }^{0} \mathrm{C}$ for 30 seconds, extension

\section{Statistical analysis}

Values were expressed as mean \pm standard deviation (SD). All numerical results were analyzed with one-way ANOVA with post hoc multiple comparisons test while student's t- test was used to compare independent variables. Gene expression results were analyzed with Chi-Square test using SPSS for windows version 20.0 statistical program. $\mathrm{P}$ values $<0.05$ were considered statistically significant.

\section{Ethics}

Ethical approval were obtained from the Ethics Committee of the Faculty of Health Science and Technology, Nnamdi Azikiwe University, Nnewi Campus, Nigeria and Lahor Research Laboratory and Medical centre in Benin City, Edo State, Nigeria with reference number LRL/ 005/014.

Table 1: Baseline physiological characteristics of the subjects.

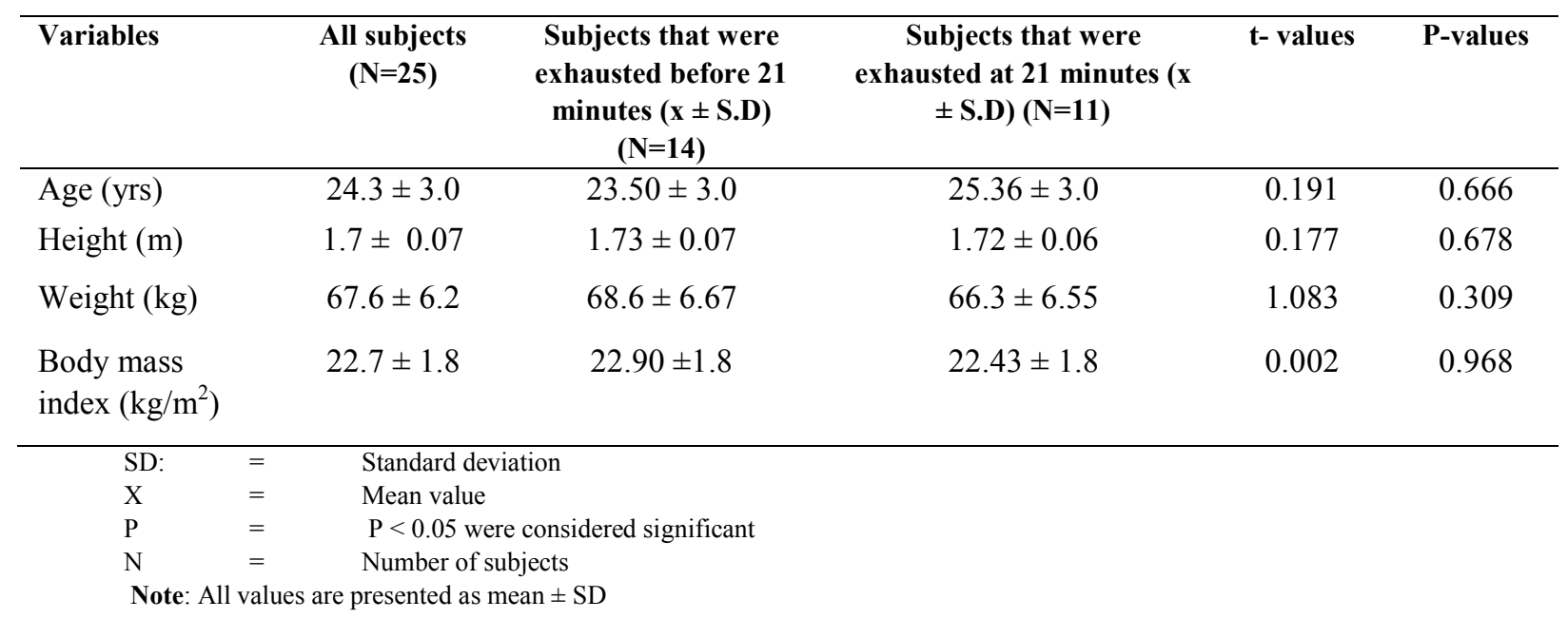




\section{RESULTS}

The study revealed that the mean \pm S.D of cortisol level of subjects who were exhausted before the end of the exercise bout (21 minutes) were $293.1 \pm 150.86 \mathrm{nmol} / \mathrm{L}$ pre-exercise, $411.0 \pm 169.71 \mathrm{nmol} / \mathrm{L}$ one hour post exercise, $246.0 \pm 155.12 \mathrm{nmol} / \mathrm{L}$ four hours post exercise and $183.4 \pm 72.83$ $\mathrm{nmol} / \mathrm{L}$ twenty-four hours post exercise. The cortisol level were significantly higher at one hour post exercise when compared with preexercise $(\mathrm{P}=0.000)$. However, there was no significant difference when compared with the four and twenty-four hours post exercise $(P=0.222)$. The mean \pm S.D of cortisol level of subjects who were exhausted at twentyone minutes of the exercise bout were 226.4 $\pm 67.95 \mathrm{nmol} / \mathrm{L}$ pre-exercise, $355.6 \pm 153.62$ $\mathrm{nmol} / \mathrm{L}$ one hour post exercise, $190.1 \pm 64.05$ $\mathrm{nmol} / \mathrm{L}$ four hours post exercise and $183.6 \pm$ $58.11 \mathrm{nmol} / \mathrm{L}$ twenty-four hours post exercise. The cortisol level were significantly higher at one hour post exercise when compared with pre exercise $(\mathrm{P}=0.000)$. Similarly, there was no significant difference when compared with the four hours post exercise $(P=0.494)$ and twenty-four hours post exercise $(\mathrm{P}=0.420)$ (Table 2$)$.

The mean \pm S.D of troponin I level of subjects who were exhausted before the end of the exercise bout were $1.7 \pm 1.83 \mathrm{ng} / \mathrm{ml}$ pre-exercise, $5.7 \pm 3.04 \mathrm{ng} / \mathrm{ml}$ one hour post exercise, $4.5 \pm 3.00 \mathrm{ng} / \mathrm{ml}$ four hours post exercise and $3.9 \pm 2.89 \mathrm{ng} / \mathrm{ml}$ twenty-four hours post exercise, the troponin I level were significantly higher at one hour post exercise, four hours post exercise and twenty-four hours post exercise when compared with pre- exercise $(\mathrm{P}=0.000)$. The mean \pm S.D of troponin I level of subjects who were exhausted at the end of the exercise bout were $3.4 \pm 1.87 \mathrm{ng} / \mathrm{ml}$ pre-exercise, $6.7 \pm$ $2.91 \mathrm{ng} / \mathrm{ml}$ one hour post exercise, $4.2 \pm 2.48$ $\mathrm{ng} / \mathrm{ml}$ four hours post exercise and $3.2 \pm 2.02$ $\mathrm{ng} / \mathrm{ml}$ twenty-four hours post exercise. The troponin level were significantly higher at one hour post exercise when compared with pre-exercise $(\mathrm{P}=0.000)$ (Table 2).

The mean \pm S.D of creatine kinase MM level of subjects who were exhausted before the end of the exercise bout were $3.7 \pm$ $1.12 \mathrm{ng} / \mathrm{ml}$ pre-exercise, $6.4 \pm 1.55 \mathrm{ng} / \mathrm{ml}$ one hour post exercise, $4.4 \pm 1.77 \mathrm{ng} / \mathrm{ml}$ four hours post exercise and $3.3 \pm 1.18 \mathrm{ng} / \mathrm{ml}$ twenty-four hours post exercise bout. The creatine kinase MM level were significantly higher at one hour post exercise when compared with pre-exercise $(\mathrm{P}=0.000)$. The mean \pm S.D of creatine kinase MM level of subjects who were exhausted at the end of the exercise bout were $3.5 \pm 1.20 \mathrm{ng} / \mathrm{ml}$ preexercise, $5.9 \pm 1.73 \mathrm{ng} / \mathrm{ml}$ one hour post exercise, $4.0 \pm 1.57 \mathrm{ng} / \mathrm{ml}$ four hours post exercise and $2.7 \pm 1.13 \mathrm{ng} / \mathrm{ml}$ twenty-four hours post exercise. The creatine kinase MM level were significantly higher at one hour post exercise when compared with preexercise $(\mathrm{F}=10.28, \mathrm{P}=0.000)$ (Table 2).

Moreover, the reverse transcriptase polymerase chain reaction results for interleukin 10 genes revealed that the genes were up-regulated at 4 hours post exercise and sustained till 24 hours post exercise at $250 \mathrm{bp}$ on a $1 \%$ agarose gel electrophoresis stained with ethidium bromide in all the exercised subjects (Plate 1 and Figure 1). 
Table 2: Mean $( \pm \mathrm{SD})$ values of the cortisol $(\mathrm{nmol} / \mathrm{l})$, troponin I $(\mathrm{ng} / \mathrm{ml})$ and creatine kinase - MM $(\mathrm{ng} / \mathrm{ml})$ of the exercised subjects.

\begin{tabular}{|c|c|c|c|c|c|c|}
\hline \multirow[t]{2}{*}{ Time intervals } & \multicolumn{2}{|c|}{ Cortisol } & \multicolumn{2}{|c|}{ Troponin I } & \multicolumn{2}{|c|}{ Creatine kinase MM } \\
\hline & $\begin{array}{c}\text { Subjects } \\
\text { exhausted } \\
\text { before } 21 \\
\text { minutes } \\
(n=14)\end{array}$ & $\begin{array}{c}\text { Subjects } \\
\text { exhausted at } 21 \\
\text { minutes } \\
(n=11)\end{array}$ & $\begin{array}{c}\text { Subjects } \\
\text { exhausted } \\
\text { before } 21 \\
\text { minutes } \\
(n=14)\end{array}$ & $\begin{array}{c}\text { Subjects } \\
\text { exhausted at } \\
21 \text { minutes } \\
(n=11)\end{array}$ & $\begin{array}{c}\text { Subjects } \\
\text { exhausted } \\
\text { before } 21 \\
\text { minute } \\
(\mathrm{n}=14)\end{array}$ & $\begin{array}{c}\text { Subjects } \\
\text { exhausted at } \\
21 \text { minutes } \\
(\mathrm{n}=11)\end{array}$ \\
\hline Pre-exercise(A) & $293.1 \pm 150.86$ & $226.4 \pm 67.95$ & $1.7 \pm 1.83$ & $3.4 \pm 1.87$ & $3.7 \pm 1.12$ & $3.5 \pm 1.20$ \\
\hline $\begin{array}{l}\text { 1hour post } \\
\text { exercise(B) }\end{array}$ & $411.0 \pm 169.71$ & $355.6 \pm 153.62$ & $6.8 \pm 3.04$ & $6.7 \pm 2.91$ & $6.4 \pm 1.55$ & $5.9 \pm 1.73$ \\
\hline $\begin{array}{l}4 \text { hours post } \\
\text { exercise }(C)\end{array}$ & $246.0 \pm 155.12$ & $190.1 \pm 64.05$ & $4.5 \pm 3.00$ & $4.2 \pm 2.48$ & $4.4 \pm 1.77$ & $4.0 \pm 1.57$ \\
\hline $\begin{array}{l}24 \text { hours post } \\
\text { exercise(D) }\end{array}$ & $183.4 \pm 72.83$ & $183.6 \pm 58.11$ & $3.0 \pm 2.89$ & $3.2 \pm 2.02$ & $3.3 \pm 1.18$ & $2.7 \pm 1.13$ \\
\hline F Value & \multicolumn{2}{|c|}{6.032} & \multicolumn{2}{|c|}{4.551} & \multicolumn{2}{|c|}{10.282} \\
\hline P Value & \multicolumn{2}{|c|}{$0.000 *$} & \multicolumn{2}{|c|}{$0.000 *$} & \multicolumn{2}{|c|}{$0.000 *$} \\
\hline A vs. B & $0.013^{*}$ & $0.016^{*}$ & $0.000^{*}$ & $0.003^{*}$ & $0.000^{*}$ & $0.000^{*}$ \\
\hline A vs. C & $0.316(\mathrm{~ns})$ & $0.494(\mathrm{~ns})$ & $0.555(\mathrm{~ns})$ & $0.468(\mathrm{~ns})$ & $0.206(\mathrm{~ns})$ & $0.414(\mathrm{~ns})$ \\
\hline A vs. D & $0.222(\mathrm{~ns})$ & $0.420(\mathrm{~ns})$ & $0.223(\mathrm{~ns})$ & $0.856(\mathrm{~ns})$ & $0.453(\mathrm{~ns})$ & $0.198(\mathrm{~ns})$ \\
\hline
\end{tabular}

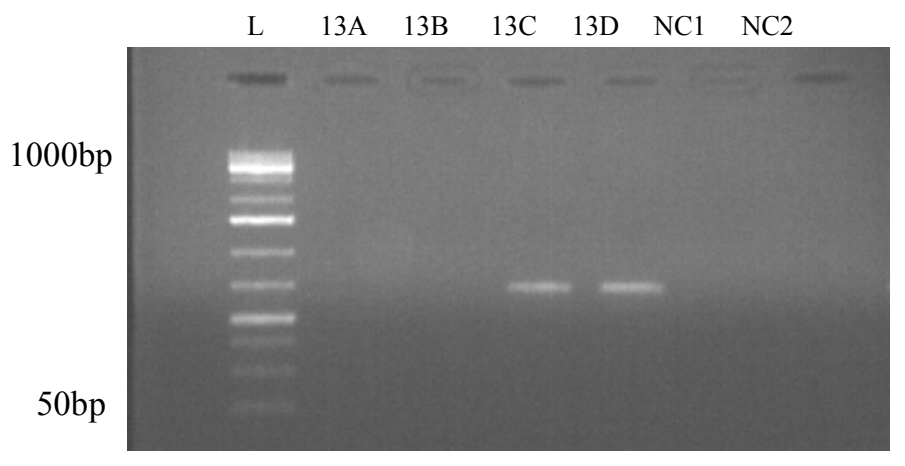

Plate 1: Reverse transcriptase PCR results for interleukin 10 genes detected in exerciseinduced stress subjects analyzed on a 1.0\% agarose gel electrophoresis stained with ethidium bromide. $\mathrm{L}$ is a $50 \mathrm{bp}-1000$ bp DNA ladder (molecular marker). Lanes 13C and 13D are positive bands for the expressed interleukin 10 genes at 250 bp from exercised subject. Lanes 13A and 13B are negative bands from the pre stage and 1 hour post exercise respectively while $\mathrm{NC} 1$ and $\mathrm{NC} 2$ are no template control.

$\mathrm{A}=$ pre-exercise

$\mathrm{B}=1$-hour post exercise

$\mathrm{C}=4$-hours post exercise

$\mathrm{D}=24$-hours post exercise 


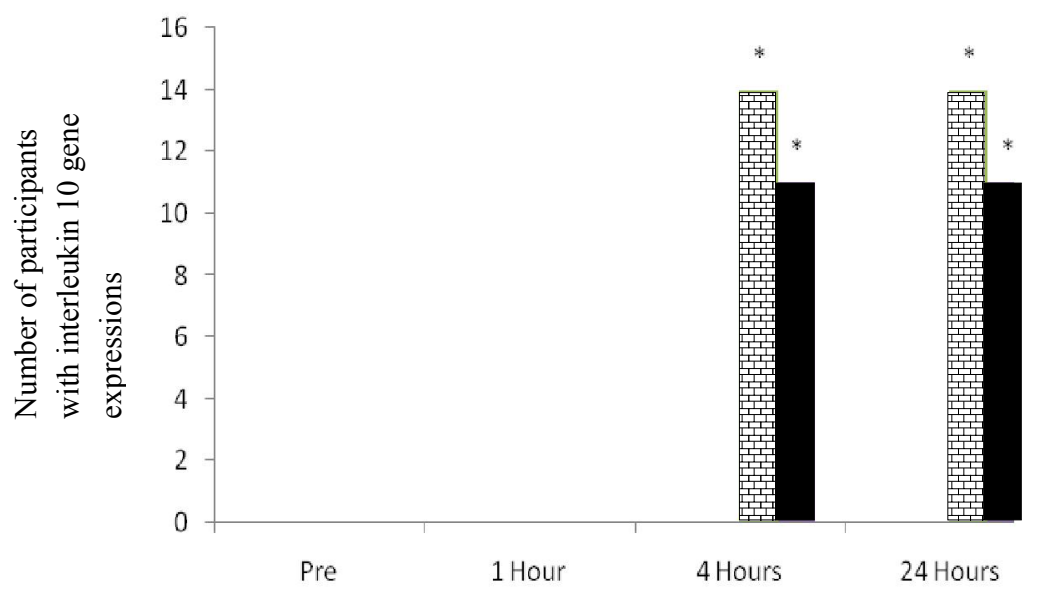

Figure 1: An overall multiple bar chart representation of the up-regulation of IL-10 gene detected in exercised subjects at different time intervals. The expression patterns were up-regulated at 4 hours post exercise and sustained till 24 hours post exercise when $\left(\chi^{2}=50, \mathrm{P}=0.000\right)$ respectively. Pre $=$ Gene not expressed in exercised participants; Bricks $=$ Gene expression in subjects who were exhausted before 21 minutes at different time intervals; Black = Gene expression in subjects who were exhausted at 21 minutes at different time intervals; ${ }^{*}=$ Significant $\mathrm{P}<0.05$

\section{DISCUSSION}

This study observed that the cortisol level of the exercised subjects was significantly higher at 1 hour post exhaustive exercise stage (approximately 9:30 am) when compared with pre-exercise stage (approximately 8: $30 \mathrm{am}$ ) (Table 2). These results support the fact that stress of any origin, whether physical or mental can greatly enhance the secretion of adrenocorticotrophic hormone and consequently cortisol. It has been reported that elevated cortisol inhibits the action of insulin thereby encouraging higher blood glucose level via gluconeogenesis and glycogenolysis (Carl and Edward, 2006; Raddatz and Ramadori, 2007). Thus, it is possible that the 1 hour post exhaustive exercise cortisol elevation observed in this study inhibits the action of insulin thereby enhancing the production of blood glucose via gluconeogenesis and glycogenolysis in an attempt to regain glucose homeostasis. Tortora et al. (2006) observed that post exercise cortisol elevation enhances the production of blood glucose from noncarbohydrate substrates such as amino acids and glycerol. This is known as gluconeogenesis.
According to Sang-Hoon et al. (2007) post exercise stress increases blood glucose utilization by enhancing both glycogenolysis and gluconeogenesis in the cell of the liver and skeletal muscles. It has been reported that glycogenolysis and gluconeogenesis enhances the release of glucose into the bloodstream during physical activity thereby ensuring that blood glucose levels do not drop below the fasting blood glucose level (Fox, 2009). Also, Holloszy (2003) reported that gluconeogenesis accounts for approximately $20 \%$ of blood glucose production during low to moderate intensity exercise in human subjects. Furthermore, post exercise cortisol elevation has been reported to stimulate the breakdown of triglycerides in adipocytes thereby enhancing the release of free fatty acid which are needed for the generation of adenosine triphosphate via the beta-oxidative pathway for muscle contractions (Brooks et al., 2005). However, there was a significant decrease of cortisol level at 4 hour post exhaustive exercise stage (approximately 1: $30 \mathrm{pm})$ and 24 hours post exercise stage (approximately 8: $30 \mathrm{am}$ ) when compared with the pre exercise stage (approximately 8 : $30 \mathrm{am}$ ). The significant decrease in cortisol 
level could be attributed to a restored homeostasis as the subjects feel relieved of the stress induced by the exhaustive exercise bout.

Humans respond to stress by activating cytokines producing cell to release both pro and anti inflammatory cytokines, the pro-inflammatory cytokines such as tumor necrosis factor alpha activate the hypothalamus-pituitary-adrenal to release cortisol into the blood-Stream in attempt to regain cellular homeostasis (Wingfield et al., 2002). The observed up-regulation in the expression patterns of the interleukin 10 genes at 4 hours post exercise and sustained till 24 hours post exhaustive exercise at $250 \mathrm{bp}$ (Plates 1 and Figure 1) might be an indication that there is an effective control of the immune responses to stress within these periods. Stenberg et al. (2000) reported that humans respond to post exercise stress by activating cytokine producing cells to induce the production of cytokine genes such as tumor necrosis factor alpha, interferon gamma; it simultaneously releases interleukin10 to effectively control immune response to stress. Bente (2006) and Rodrigo et al. (2012) in their studies reported that post exercise stress enhances the up-regulation of interleukin-10 genes in attempt to regain cellular homeostasis during muscle contractions. However, other work demonstrated that interleukin-10 levels are elevated during strenuous exercise (Ostrowski et al., 2000). Although Peake et al. (2005) reported that exercise induced muscle fatigue can up-regulate interleukin-10 genes. Nieman et al. (2005) also observed that 30 minutes' walk increases the level of interleukin-10 genes in young male students.

It has been reported that adenosine triphosphate generated from anaerobic metabolism (phosphocreatine, stored adenosine triphosphate and anaerobic glycolysis) and aerobic metabolism modulates the sliding of actin along the length of myosin to achieve muscle contraction (Kenney et al., 2012). The essential role of anaerobic glycolysis during muscle contraction is manifested in the elevation of blood lactate level from 1.6 to $8.3 \mathrm{mM}$ in actively contracting muscles (Jeremy et al., 2001).
Moreover, aerobic metabolism is the major source for adenosine triphosphate production from blood glucose, glycogen and triglycerides during exercise that last longer than 2 to 3 minutes. Unlike anaerobic adenosine triphosphate production, the aerobic metabolism system is slow to turn on; but it has a much larger adenosine triphosphate producing capacity, this places considerable demands on the cardiovascular and respiratory system to deliver oxygen to the active muscles (Kenney et al., 2012). These changes are essential for producing adenosine triphosphate required for supporting muscle contractions. Goett et al. (2011) and Marianne et al. (2012) reported in their studies that an increased mechanical stress on the contracting muscles during exhaustive exercise can significantly elevate the level of troponin inhibitory and creatine kinase. Thus, it is probable that the 1 hour post exercise elevations of troponin inhibitory and creatine kinase are indicative of an increased mechanical stress on the contracting muscle during the exhaustive exercise bout. However, there were no significant differences observed at 4 hours and 24 hours post exercise elevation of troponin inhibitory and creatine kinase-3 when compared with the pre-exercise stage (Table 2). This is suggestive of a restored homeostasis as the subjects feel relieved of the mechanical stress induced by the exhaustive exercise bout.

\section{Conclusion}

The post exercise elevation of creatine kinase-3 and troponin I level are indicative of an increased mechanical stress on the contracting muscles during the exhaustive exercise bout. Furthermore, post exercise stress activates the release of cortisol, and interleukin-10 genes to reinstate homeostasis through modulation of the immune response.

\section{COMPETING INTERESTS}

The authors declare that they have no competing interests.

\section{AUTHORS' CONTRIBUTIONS}

This work was carried out in collaboration with all the authors. Authors EFA, OCC and ACO designed the study, 
conducted the exercise protocol and performed the statistical analysis. Authors EFA, ADE and EIJ conducted and managed the Laboratory analysis. All the authors read and approved the final manuscript.

\section{ACKNOWLEDGEMENTS}

We acknowledge the cooperation of the members of staff of the Lahor Research Laboratory, Benin City, Nigeria and the Medical Rehabilitation Department, Faculty of Health Sciences and Technology, Nnamdi Azikiwe University, Nnewi Campus, Nnewi, Nigeria.

\section{REFERENCES}

Adam JR, Erik AR. 2005. Skeletal muscle glucose up-take during exercise: How is it regulated. American Physiological Society, 20: 260-270. DOI: http:// 10.1152/physiol.00012.

Bente KP. 2006. The anti-inflammatory effect of exercise: its role in diabetes and cardiovascular disease control. The Biochemical Society, 42: 105- 117.DOI: http:10.1042/bse0420105.

Brooks GA, Fahey TD, Baldwin KM. 2005. Exercise Physiology: Human Bioenergetics and its Application. McGraw-Hill Publishing: Columbus; 125- 134.

Carl AB, Edward RA. 2006. Tietz Fundamental of Clinical Chemistry $\left(5^{\text {th }}\right.$ edn). Saunder: Philadelphia, Pennsylvania; 432- 437.

Dos-Santos JM, Moreli ML, Tewari S, Benite-Ribeiro SA. 2015. The effect of exercise on skeletal muscle glucose uptake. An Epigenetic Perspective Metabolism, 64: 1619-1628. DOI: http:// 10.1016/j. metabol.

Ehiaghe FA, Agbonlahor DE, Ositadima, MI, Ehiaghe IJ, Osadolor HB. 2013. Effect of academic stress on serum cortisol and CD4+ $\mathrm{T}$ cell count in young male post graduate students in Okada, Nigeria. International Journal of Biological and Chemical Sciences, $\mathbf{8}$ : 1249-1253.

DOI: http://dx.doi.org/10.4314/ijbcs.v8i3.37

Elenkor IJ, Chrousos E. 2002. Stress hormones, proinflammatory and anti- inflammatory Cytokines and autoimmunity. Annals of Academic Science. 966: 290-303. DOI: http:// scholar.google. dk.

Fox SI. 2009. Fundamentals of Human Physiology. McGraw-Hill: New York; 33- 42.

Goette A, Bukowska A, Dobrev D. 2009. Acute atrial tachyarrhythmia induces angiotensin II type 1 receptormediated oxidative stress and microvascular flow abnormalities in the ventricles. European Heart Journal, 30:1411-1420. DOI: http:// doi.org/ 10.1093/eurheart/ehp046.

Gosker HR, Scholes AM. 2008. Fatigued muscles in COPD but no finishing line in sight. European Respiratory Journal, 31:693-694. DOI: http:10.1183109031936.00015308.

Hackney AC, Walz EA. 2013. Hormonal adaptation and the stress of exercise training: the role of glucocorticoids. Trends in Sport Sciences, 20: 165- 171. DOI: http:// www.tss.awf.poznan.

Holloszy JO. 2003. A forty-year memoir of research on the regulation of glucose transport into muscle. America Journal of Physiology, 284: 453- 467. DOI: https:// www.ncbi.nlm.nib.gov/ pubmed12556346.

Hu FB, Manson J, Stampfer M, Graham C. 2001. Diet, Lifestyle and risk of type 2 diabetes mellitus in women. The New England journal of Medicine, 11: 790 $797 . \quad$ DOI: http:// www10.1056/NEJMoa010492.

Jeremy MB, John LT, Lubert S. 2001. Biochemistry (5th Edn). W.H.Freeman and company: New York; 465-695.

Kenney WL, Wilmore JH, Costill DL. 2012. Physiology of Sport and Exercise. Amy N. Tocco; Human Kinetics, Champaign: United states; 55- 64.

Kristin IS, Laurine JG. 2014. Molecular mechanism regulating glucose up-take in skeletal muscle. Advances in Physiology Education, 38: 308-314. DOI: https:// www.ncbi.nim.nih.gov/pubmed/2543401 3. 
Marianne FB, Scott MG, Julian SB, Gordon FB. 2012. Creatine-kinase and exerciserelated muscle damage implication for muscle performance and recovery. Journal of Nutrition and Metabolism, 12: 13-19. DOI:https://www.hindawi.com/journal/jn me/960363.

Mery TL, McConell GK. 2009. Skeletal muscle glucose uptake during exercise: a focus on reactive oxygen species and nitric oxide signaling. Life, 61: 479-484.

DOI:https://www.ncbi.nim.nih.gov/pubmed/ 190363.

Nieman DC, Henson DA, Austin MD, Brown VA. 2005. Immune response to a 30-minuteswalk. Medical Sport Exercise, 3: 57-62. DOI: https://www. ncbi.nlm.nih.gov/pmc/articles/PMC4612 317.

Ogwumike OO, Arowojolu AO, Sanya AO. 2011. Effects of a 12- week endurance exercise program on adiposity and flexibility of Nigerian perimenopausal and postmenopausal women. Nigerian Journal of Physiology Sciences, 26: 199206. DOI: https://www.ncbi.nlm.nih.gov/ pmc/articles/PMC4006210.

Olesen J, Kiilerich K, Pilegaard H. 2010. PGC-1 alpha -mediated adaptations in skeletal muscle. European Journal of Physiology, 450:153-162. DOI: https://www.ncbi.nlm.nih.gov/pubmed/2 0401754.

Peake JM, Suzuki K, Wilson G, Hordern M, Nosaka K, Mackinnon L, and Coombes J. 2005. Exercise-induced muscle damage, plasma cytokines and markers of neutrophil activation. Medical Science Journal of Sport Exercise, 37: 737- 745. DOI: http://hms.health.uq.edu.au/ biochem.

Raddatz D, Ramadori G. 2007. Carbohydrate metabolism and the liver: actual aspects from physiology and disease. Gastroenterology, 45: 51-62. DOI: https://www.ncbi.nlm.nih.gov/pubmed/1 7236121.
Rodrigo T, Silvia AC, Veronica SP, Patricia ML. 2012. Effect of exercise on the immune sytem: response, adapation and cell signaling. Exercise and Sport Science, 18: 34- 49. DOI: http://www.scielo.br/scielo.

Sahoo S, Khess CR. 2010. Prevalence of depression, anxiety and stress among young male adults in India: a dimensional and categorical diagnosesbased study. Journal of Nervous and Mental Diseases, 198: 901-904. DOI: https://www.ncbi.nlm.nih.gov/pubmed/2 1135643.

Stampfer MJ, Hu FB, Manson JE, Rimm EB, Willet WC. 2000. Primary prevention of Coronary Heart Disease in Women through Diet and Lifestyle. New England Journal of Medicine, 1: 16-22. DOI: http://www.nejm.org/doi/full/10.1056/nej m200007063430103.

Stenberg A, Van-Hall G, Osada T. 2000. Production of interleukin-6 in contracting human skeletal muscles can account for the exercise- induced increase in plasma interleukin-6. Journal of Physiology, 529: 237- $242 . \quad$ DOI: https://www.ncbi.nlm.nih.gov/pmc/articl es/PMC2270169.

Tortora GJ, Derrickson B. 2006. Principle of Anatomy and Physiology $11^{\text {th }}$ Edition: Wiley and Son. Hoboken; 220- 234.

Vanessa N, Elizabeth D. 2000. Submaximal exercise testing: Clinical application and interpretation. Journal of the American Physical Therapy Association, 80: 782807. DOI: https://www.idosi.org/mejsr/ mejsr.

Wingfield JC, Maney DL, Breuner CW, Jacobs JD, Lynn S, Ramenofsky M, Richardson RD. 2002. Ecological bases of hormone-behavior interactions: the emergency life-history stage. American Zoologist, 38: 191-206. DOI: https://beheco.oxfordjournals.org/content/15 /2/313. 